\title{
Democratic Leadership and Attitude towards Time Management of the Student Leaders
}

\author{
Dr. Jerald C. Moneva \\ Department of Education \\ Mandaue City Division, Cebu, Philippines \\ E-mail: monevajerald5@gmail.com \\ John Patrick M. Pedrano \\ Jagobiao National High School \\ North Road, Jagobiao Mandaue City \\ E-mail: johnpatty1120@gmail.com
}

Received: February 8, 2020 Accepted: February 28, 2020 Published: March 13, 2020

doi:10.5296/ijld.v10i1.16662ＵRL: https://doi.org/10.5296/ijld.v10i1.16662

\begin{abstract}
Nowadays, lots of students involve themselves in leadership at school which include the class officers wherein they are also known as student leaders who lead democratically. However, while students are practicing democratic leadership at school, some are having a hard time in managing their time properly. Therefore, time management attitude is essential to the students and more importantly to those who are leaders at school. This study aims to determine the association between the level of democratic leadership and the level of time management attitude of the class officers. The data regarding democratic leadership and time management attitude were collected from a sample of 200 class officers from all grade levels in junior high school and senior high school department. With the 200 respondents who answered the survey, the findings of the study revealed that the level of democratic leadership is highly associated with the level of time management attitude. Thus, there is a significant relationship between the level of democratic leadership and the level of time management attitude. Overall, as the level of democratic leadership increases, the level of time management attitude also increases. The
\end{abstract}


study suggests that student leaders like class officers and others should improve their time management attitude through seeking advices for best strategies and to explore more deeply on democratic leadership to be able to successfully apply it in school.

Keywords: Democratic Leadership, Democracy, Time Management Attitude

\section{Introduction}

A leader is simply a person who leads and influences people to achieve a certain goal and purpose. Being a leader is not easy. They must possess qualities to become effective. A leader doesn't only set direction and vision but also uses management skills to guide his people to the right destination in a smooth and efficient way.

There are six types of leadership styles named such as autocratic leadership, bureaucratic leadership, charismatic leadership, democratic/participative leadership, laissez-faire leadership, and transactional leadership (Amanchukwu, Stanley \& Ololube, 2015). It is emphasized that democratic leadership was more effective for group performance among other leadership styles because the goals of a group are not imposed on the leader himself but are rather achieved by the group as a whole (Kavanagh, n.d.). Moreover, democratic leadership is found out to be the preferred strategy to attain the school improvement (Somech, 2005).

Leaders do not only focus in achieving one goal at a time, instead they should be efficient to achieve more goals at a given time allotment. They need to have discipline among themselves and learn to create intimate relationships between their members. In fact, group participation and member relationships are being emphasized in democratic leadership even in small groups and organizations (Choi, 2007). Furthermore, being a student leader is a great responsibility. Student leaders are also expected to act as leaders that can create a great impact to the students (Muthoni, Njagi \& Wambugu, 2018). They need to balance their time excelling on their studies as well as succeeding in different school activities. Thus, leaders need to possess a positive attitude towards time management to become effective and efficient on their own. It is the time management that enables a student to improve his performance is and achievements (Mohamed, Hamal \& Mohamed, 2018).

A leader is an important person that everyone should have become. It is significant in a sense that it makes each individual develop their character and discover their talents and abilities through leading. It is important for the youth to have experienced leadership at a young age for them to become aspiring leaders of the future generations. Moreover, leadership is not all about knowing positions but is the capability to handle people, situations and proper time management while showing off the characteristics of an effective leader in doing such things.

Relatively, Jagobiao National High School students make a difference through leadership. There are students who seemed to become potential leaders in their respective classes and even in the school as a whole. This difference enables to determine how student leaders use democratic leadership in school and what attitude do they possess in managing their time as a student and at the same time as a democratic student leader. 


\subsection{Theoretical Background}

This study is primarily anchored on the Blake and Mouton's Managerial Grid or also known as the Grid Theory of Leadership. It is a model developed by Robert R. Blake and Jane Mouton in 1964. This model is based on two behavioral dimensions such as Concern for People which is represented by a vertical axis and Concern for Results which is represented by a horizontal axis. This managerial grid is developed to assess the degree to which leaders are concerned with either results or the people. The significance of the managerial grid relates to understanding more about how a leader views himself and how his members see him. This also suggests that equal emphasis on task and relationship factors are important, regardless of members. Leaders score between 1 which represents the least concern and 9 which represents the maximum concern on each axis. Because of the score combinations, 5 leadership styles were identified. First, the country club leadership which is plotted at the top-left corner of the grid and shows the most concern for people but the least concern for production. Second, the impoverished leadership which is plotted at the bottom-left corner of the grid and shows the least concern for production and people. Third, the middle-of-the-road leadership which is plotted in the center of the grid and shows balanced concern for production and people. Fourth, the team leadership which is plotted at the top-right corner of the grid and stresses high production from the members. Last, the authoritarian or perish leadership which is plotted at the bottom-right corner of the grid and stresses high production with little concern for member satisfaction (Zeidan, 2009).

Hence, team Leadership can also be considered as a democratic Leadership because it also involves the participation of the members to achieve highly desirable goals. It was also found out based on the results of the classic study of leadership conducted by Kurt Lewin in 1939 that Democratic Leadership was more effective for group performance among other leadership styles (Kavanagh, n.d.).

Democratic leaders encourage cooperation and ideas from their group members to help the members feel comfortable and committed to the decision-making process within the group. Leadership has a big impact on the project or the goals of an organization through teamwork (Jiang, 2014). This theory also suggests that the most effective leaders are ones who take into consideration the ideas, suggestions and concerns of others. This means that the best ideas are not always given by the leaders but are coming from the minds of the other members. This is why there is a need to discover new suggestions or opinions from others and involve them in the decision-making process to come up with the best decisions. In addition, Democratic leaders have huge responsibilities because they emphasize collaboration and free-flow of ideas but ultimate decision-making power lies with them.

There are many benefits of democratic leadership. Team members tend to have productivity because they are more involved. This leadership style helps develop the members' skills. By this, team members feel a part of something meaningful and are so motivated to achieve the desired goals of the team. Though there are many benefits, there is also a danger in democratic leadership wherein it can falter in situations where speed or efficiency is essential. Another potential danger is team members without the knowledge or expertise to provide high quality 
input.

Despite these potential dangers, it must be realized that democratic leadership is helpful within a group to discover the members' creativity in making decisions and this can help them grow and develop themselves. Through decision-making, their level of maturity in thinking would perhaps increase. Particularly, democratic leadership is what needs to be practiced by students in school for them to realize that they shouldn't always rely on their leaders in terms of group performances, activities and reporting. Instead, they should believe that they also have the capabilities to contribute ideas for the betterment of the performance and the group as well.

\subsection{Statement of Purpose}

This study intends to assess the level of attitude towards time management, extent of class officers' practice of democratic leadership, and determine the association of both, if any.

\section{Hypothesis}

Null: There is no association between the levels of democratic leadership being practiced by the class officers in their classroom and the level of their time management attitude.

Alternative: There is an association between the levels of democratic leadership being practiced by the class officers in their classroom and their level of time management attitude.

\subsection{Significance of the Study}

The findings of the study will benefit the following:

First, the students of Jagobiao National High School will benefit from this study because they will have an idea about democratic leadership and the different levels of time management attitude and they will also know how to apply democratic leadership and level of time management attitude on their classrooms both in oneself and within a group.

Second, the class officers will also benefit from this study in a way that they will be able to enhance the democratic leadership they have performed in their respective classrooms and practice having time management attitude both in being a leader and a student.

Third, the teachers will also benefit from this study because they will gain knowledge about democratic leadership and time management attitude and they will be able to help or encourage the students to transform themselves into democratic leaders and as well as to become time-efficient students.

Fourth, this will also benefit the parents in such a way that they will be able to guide their children on their way of becoming effective democratic leaders in school and they will be able to determine and show the different levels of time management attitude to the students which could be useful in leading.

Fifth, the school head will also benefit from this study by gaining awareness pertaining to the democratic leadership and time management attitude practiced by the students in their classrooms and suggest better strategies to the teachers on how to enhance the time management attitude of the students in terms of leadership. 
Sixth, the community will also benefit from this study through gaining deeper knowledge about democratic leadership and time management attitude and eventually apply this knowledge in the community through the organizations present in the community for the betterment of the society.

Last, other researchers can also benefit from this study in a way that they can use this as a support of their own researches and this can serve as one of their sources in their study.

\subsection{Definition of Terms}

The following terms are operationally defined to help the readers determine the meaning and the usage of the unfamiliar words in the study.

Democratic Leadership is a type of leadership style which emphasizes collaboration and involvement of other members within a group.

Level of Time Management Attitude is the degree of attitude to which the students show or how they behave in terms time management.

Class Officers are the student leaders who lead the class which is headed by their advisers.

\section{Review of Related Literature}

Leadership is one of the greatest factor that contributes to project success and it influences the teamwork, management, and communication between the members and leaders (Jiang, 2014). Leadership is the key to manage a successful organization (Dalluay \& Jalagat, 2016). In educational organizations, it appears that servant leadership may be used as a means to create changes within the organization. Servant leadership is a kind of leadership that requires time and gives many opportunities to all learners. (Crippen, 2005). In fact, it is also found out that high task and high relationship work best in finishing a certain project and in putting trust to the members (Kavanagh, n.d.). Findings have also shown that even in small groups, leaders have involved the members and acknowledge their ideas in the decision-making processes and have therefore ruled by democratic decisions (Jorge \& Marques, 2012).

Moreover, school leaders are encouraged to seek for different strategies that could enable them to achieve best results in school. An educational leadership style could be effective if appropriate application is being observed (Amanchukwu, Stanley \& Ololube, 2015). Also, student leaders recognize their own weaknesses and engage in trainings to enhance their leadership skills because when one leads others, he is required to understand the vision of the organization and task delegations. (Muthoni, Njagi \& Wambugu, 2018). Furthermore, leaders with strong leadership are capable of leading any organizations (Miller, 2012). Democratic educational leaders also establish conditions that can easily lead to the social, learning, and cultural responsiveness development of the organizations and apply strategies in order to possibly gain achievements (Gale \& Densmore, 2003). Leaders also face new challenges such as meeting high demands and better performances in this more competitive educational system environment (Somech, 2005).

The characteristics of democratic leadership in democratic movements such as sacrifice, 
courage, and vision are needed in order to achieve democracy and to encourage the people to participate (Choi, 2007). The criteria for holistic democracy could enable the schools to explore their leadership practice and to reflect critically on existing leadership policies (Rawson, 2011). In addition, Kensler's new proposed framework about conception of democracy aims to deeply understand the practice of democratic principles within more sustainable organizations (Kensler \& Woods, 2012).

Aside from the educational context, democratic leadership is of the essence in the business or work setting as well. As a matter of fact, findings have shown that employees who face democratic leadership from their leaders are satisfied with their jobs without thinking of looking for other jobs; thus, it is the sense of ownership among the employees that made them satisfied. (Bhatti, Maitlo, Shaikh, Hashmi \& Shaikh, 2012). Though democratic leadership from the leaders makes the employees have job satisfaction, it still important for managers or leaders to be educated about motivation and leadership. In fact, they are encouraged to learn about these through continued education and practical practices (Fisher, 2009).

As democratic leadership plays a vital role in the society, either in an educational context or business setting, it is also important to consider that every democratic leader's level of time management attitude affects their level of democracy in leadership. Time management is self-management wherein time is equally distributed to everyone, but not all have used them productively (Rombe, 2016). Time management is the most important task that a student must do to achieve success (Mohamed, Hamal \& Mohamed, 2018). Students with good time management skills are capable of organizing and prioritizing things without putting other things behind and they can also arrange time in order to get a task done on time (Khatib, 2014). Time management capabilities also serve as a guide for the students on their studies (Lay \& Schouwenburg, 2007). Thus, students who become successful are considered as good time managers (Nasrullah \& Khan, 2015).

Having expectations as challenges are also experienced by the students (Meer, Jansen \& Torenbeek, 2010). By that, it was found out that students often mentioned time pressures as a stressor (Jogaratnam \& Buchanan, 2004). The use of social networking sites is also found out to be a temptation for students, but it has nothing to do with the time spent by the students on their schoolwork (Panek, 2013). In addition, results have also shown that as the difficulty of task increases, more appropriate time management is needed by the students (Liu, MacCann \& Roberts, 2009). However, it was also found out that as the anxiety levels of the students increase, it becomes more difficult for them to be able to control time (Akcoltekin, 2015). Furthermore, since procrastination impacts academic performance, based on findings, students should strive hard to finish their homework as well as other tasks before the deadline comes (Adebayo, 2015) because an improved homework time management can also improve a student's academic achievement (Nunez, Suarez, Rosario, Vallejo, Valle \& Epstein, 2015).

Despite these challenges, there are also mechanisms suggested to successfully improve one's time management. Given that time management skills can be trained, it is suggested that the use of training programs could possibly result to an improved academic achievement, especially those students who are poor time managers. Acquiring scholarship programs also 
affect a student's use of time and it allows the students to experience both academic and nonacademic activities in school (DesJardins, McCall, Ott \& Kim, 2010). In addition, providing materials such as calendars, planners, etc. to the students and encouraging them to use these materials can help them form good time management habits and can contribute to the improvement of their performance in school (Nadinloyi, Hajloo, Garamaleki \& Sadeghi, 2013). All in all, the higher the capacity of a person to manage his time well, the higher the quality of life he has (Wang, Kao, Huan \& Wu, 2011).

Time management attitude is vital for people especially those who are students and democratic leaders at the same time to achieve academic success as well as having experiences related to leadership in school.

\section{Research Methodology}

\section{Design}

The research study used a descriptive correlational design. This is used to determine the association between the student's level of time management attitude and the level of democratic leadership being practiced by the class officers in their respective classrooms.

\section{Locale \& Respondents}

The study was conducted in the Senior High School (SHS) Department and Junior High School (JHS) Department of Jagobiao National High School, Mandaue City, Cebu, Philippines. The respondents of this research study were the class officers in each section per grade level from Grade 7 to Grade 12. The study needed all the class officers in both Junior High School and Senior High School Department. This study has an overall respondents of 200 students.

\section{Instrument}

The researcher used an adopted Likert Scale in gathering data and information for it is the best tool for this quantitative study. This instrument is a set of questionnaires given to the respondents wherein they will rate the questions according to their own perceptions from (3) for strongly agree, (2) for agree, and (1) for disagree. A survey questionnaire is adopted from Osswatch (2014) with 10 indicators for Democratic Leadership. Also, another survey questionnaire is adopted from Wayne State University (2007) with 10 indicators for Time Management Attitude.

\section{Data Gathering Procedure}

The researcher asked the permission from the school head and the teachers to conduct the data gathering in every classroom with the help of a letter of consent signed by the teacher and principal. The researcher gave a sheet of paper to each respondent. Then, he lent the questionnaires written on a bond paper. Next, the researcher gave 5 minutes for the respondents to answer the questionnaires. The researcher also entertained questions from the respondents pertaining to their confusions about the given set of questions. Afterwards, the researcher expressed his gratitude to the respondents for their cooperation. The researcher's collected data would be the basis of his analysis, interpretation, conclusions, findings, and the 


\section{Macrothink}

recommendation of his study.

\section{Statistical Treatment}

The researchers will use the weighted mean and chi-square for the interpretation of data. The chi-square statistic is commonly used for testing relationships between categorical variables. The chi-squared test will be used to determine the significant relationship between the level of democratic leadership practiced by the class officers in their respective classrooms and the level of their time management attitude.

\section{Ethical Statement}

During the research making process, there are no persons harmed nor injured. The names are kept sacred and anonymous to assure identification of the respondents. The questionnaires are only answered within 15 minutes. Afterwards, the answer sheets are shredded and digital electronics were deleted after the study.

\section{Presentation, Analysis and Interpretation of Data}

Table 1. Level of Democratic Leadership of Class Officers

$\begin{array}{lll}\text { Indicators } & \text { WM } & \text { Interpretation }\end{array}$

1. I always try to include one or more team members in determining what to do and how to do it. However, I maintain the final decision making authority.

Sometimes

2. I ask for ideas and input into upcoming plans and activities.

At all times

3. When things go wrong and I need to create a strategy to keep a project or process running on schedule, I call a meeting to get my team members advice.

At all times

4. I want to create an environment where team members take ownership of the project. I allow them to participate in the decision making process.

At all times

5. I ask team members for their vision of where they see their work going and then use their vision where appropriate.

At all times

6. I allow my team members to set priorities with my guidance.

Sometimes

7. When there are differences in role expectations, I work with them to resolve the differences. 
9. Team members will exercise self-direction if they are committed to the objectives.

10. Team members know how to use creativity and ingenuity to solve organizational problems.

Sometimes

OVERALL WEIGHTED MEAN

LEGEND: 1.00-1.66 (Not at all); 1.67-2.33 (Sometimes); 2.34-3.00 (At all times)

The table above shows that the overall weighted mean is 2.36 which signifies that the class officers' level of democratic leadership in school is high. The statement "I ask for ideas and input into upcoming plans and activities" is an indicator that has a weighted mean of 2.56 and is labeled as the highest among other indicators which implies that the class officers value the ideas from their members or in other words, the class officers involve their members in the decision-making processes. In addition, Gale \& Densmore (2003) also stated that in order to reach agreements, there is a need to involve others in the exchange of ideas. It is then followed by the statement "I like to use my leadership power to help team members grow" with a weighted average of 2.48 and is labeled as the second highest among the indicators. It tells that the class officers use the power that they have in the classroom to help their members grow as an individual. In fact, Kensler \& Woods (2012) said that for individuals to grow as whole people, other members also need to be involved, trusted and respected because they will be truly affected in any decisions that are made. On the other hand, the statement "Team members will exercise self-direction if they are committed to the objectives" has a weighted mean of 2.19 in which it is labeled by the respondents as "sometimes" is found to be the least indicator of the democratic leadership practiced by the class officers in the school. Nevertheless, Bhatti, Maitlo, Shaikh, Hashmi \& Shaikh (2012) found out that democratic leaders take great care of their members to be able to work with a highly motivated team. 
Table 2. Level of Democratic Leadership of Class Officers

\begin{tabular}{lll}
\hline Category & Frequency & Percentage \\
\hline Not at all & 0 & $0 \%$ \\
Moderately Democratic & 36 & $18 \%$ \\
Democratic & 164 & $82 \%$ \\
\hline TOTAL & $\mathbf{2 0 0}$ & $\mathbf{1 0 0 \%}$ \\
\hline
\end{tabular}

LEGEND: 1-10 (Not at all); 11-20 (Moderately Democratic); 21-30 (Democratic).

The table above shows that the majority of the class officers who have scored 21-30 has the highest percentage of $82 \%$ and is interpreted as "democratic". It is followed by a few class officers who have scored 11-20 and has a percentage of $18 \%$ and is labeled as "moderately democratic". It was revealed that most of the class officers that answered the questionnaire is democratic. Therefore, the class officers' extent of practice of leadership is democratic. In addition, Harris \& Chapman (2002) stated that there is an emphasis on the democratic approach of leadership at school in order for the distribution of leadership and empowerment of others to happen. Woods (2004) also stated that there is a need for school leaders to protect and promote the ideas, concepts, and values of democracy in the context of education.

Table 3. Level of Time Management Attitude of Class Officers

\begin{tabular}{llc}
\hline Indicators & WM & Interpretation \\
\hline 1. I do things in order of priority. & 2.34 & At all times \\
2. I accomplish what needs to be done during the day. & 2.23 & Sometimes \\
3. I feel I use my time effectively. & 2.10 & Sometimes \\
4. I spend enough time planning. & 2.12 & Sometimes
\end{tabular}

5. I am able to meet deadlines without rushing at the last minute.

$2.04 \quad$ Sometimes

6. I spend enough time on academic matters.

$2.16 \quad$ Sometimes 
7. I prioritize my list in order of importance, not urgency. $\quad 2.21 \quad$ Sometimes

8. I periodically re-assess my activities in relation to my goals.

Sometimes

9. My actions are determined primarily by me, not by circumstances or by other people's priorities.

$2.24 \quad$ Sometimes

10. I am satisfied with the way I use my time.

At all times

OVERALL WEIGHTED MEAN

Sometimes

LEGEND: 1.00-1.66 (Not at all); 1.67-2.33 (Sometimes); 2.34-3.00 (At all times)

From the table, it can be gleaned that the overall weighted mean is 2.21 which signifies that the level of time management attitude of the class officers is only average. The statement "I am satisfied with the way I use my time" is an indicator that has a weighted mean of 2.37 and is labeled as the highest among other indicators. Because it is labeled as "at all times", it implies that the class officers use and balance their time well. The statement "I do things in order of priority" follows next with a weighted mean of 2.34 which indicates that class officers do the tasks according to their priorities. However, Akcoltekin (2015) observed that though students planned their time according to their priorities, they still need to seek help from professionals regarding to the active and proper use of time. On the other hand, the statements "I feel I use my time effectively" with a weighted mean of 2.10 and "I am able to meet deadlines without rushing at the last minute" with a weighted mean of 2.04 appeared to be the two of the least among the indicators wherein the respondents labeled it as "sometimes". This implies that class officers are not that effective in using their time and they are usually rushing when meeting deadlines. In addition, Meer, Jansen \& Torenbeek (2010) also observed that reminding students about the forthcoming tasks and deadlines is not emphasized in high school. On the contrary, Khatib (2014) stated that students with good time management skills can finish tasks on time and can organize things well without crashing others. 
Table 4. Level of Time Management Attitude of Class Officers

\begin{tabular}{lll} 
Category & Frequency & Percentage \\
\hline Poorly managed & 0 & $0 \%$ \\
Moderately managed & 64 & $32 \%$ \\
Well Managed & 136 & $68 \%$ \\
\hline TOTAL & $\mathbf{2 0 0}$ & $\mathbf{1 0 0 \%}$ \\
\hline
\end{tabular}

LEGEND: 1-10 (Poorly Managed); 11-20 (Moderately Managed); 21-30 (Well Managed)

The table above shows that the class officers who have scored 21-30 has the highest percentage of $68 \%$ and is interpreted as "Well managed". It is followed by a few of class officers who have scored 11-20 with a percentage of 32\% and is interpreted as "Moderately managed". It was revealed that majority of the class officers' attitude towards time is well managed. Therefore, the class officers have a high level of attitude towards time management. Alzalet \& Sandybayev (2015) stated that time management positively impacts the accomplishment of a goal, in setting and organizing an objective and the time itself. Adeojo (2012) also added that being well organized in terms of time can be acquired through consistent practice and experience.

Table 5. Association of the level of Democratic Leadership and level of Time Management Attitude

\begin{tabular}{llll}
\hline & Value & df & Asymp. Sig. (2-sided) \\
\hline Pearson Chi-Square & $37.305 \mathrm{a}$ & 1 & .000 \\
Likelihood Ratio & 35.135 & 1 & .000 \\
Linear-by-Linear Association & 37.118 & 1 & .000 \\
\hline N of Valid Cases & 200 & & \\
\hline
\end{tabular}

a. 0 cells $(.0 \%)$ have expected count less than 5 . The minimum expected count is 11.52 . 


\section{Macrothink}

\section{b. Computed only for a $2 \times 2$ table}

The table above expresses that the computed p-value is .000 which is lesser than the given p-value which is .05. Because $.000<.05$, the null hypothesis is rejected. Based on the results, it can be inferred that there is a significant relationship between the levels of democratic leadership of the class officers in relation to the level of their time management attitude. Mullins (n.d.) also observed the same results in such a way that for a leader to become effective, one must learn to manage their time properly and prioritize their efforts. Moreover, Young (2010) stated that time management is important to any student, specifically to those who are involved in student organizations.

\section{Summary of Findingds, Conclusion, and Recommendation}

\section{Findings}

In this study, it was found out that the level of attitude of the student leaders specifically the class officers towards time management is average and is labeled as "sometimes". Yet, it is found out that as class officers, they are already satisfied with the way they use their time.

On the contrary, the class officers practice democratic leadership at a high level in school and is labeled as "at all times". As class officers, they intend to consult their members for their ideas before making decisions in the class to help them grow and build intimate relationships among their members.

This study reveals a significant relationship between the level of democratic leadership practiced by the class officers in their classrooms and the level of their attitude towards time management.

\section{Conclusion}

Organizations are composed of a leader and subordinates. Similarly, a classroom is composed of class officers who are considered as student leaders and members. Democratic leaders in any context they may be have visions for the whole team and acquire the power to decide at the same time maintain the intimate relationships between their members. With several priorities in life, leaders need to manage their time. To become effective, a high level of democratic leadership and time management attitude is needed. By that, they are able to inspire, influence, and create aspiring democratic leaders with a strong commitment to time.

\section{Recommendations}

Based on the findings and the discussions of this research study, the following recommendations are made:

1. The student leaders- not limited to class officers only- should enhance their leadership skills especially democratic leadership by involving or engaging themselves in the different school activities. 


\section{Macrothink Institute ${ }^{\mathrm{TM}}$}

2. The class officers or student leaders should consult advices on how to manage time properly and research for the best strategies that can be used to help them become good time managers.

3. An assessment on democratic leadership and time management attitude is needed to determine the extent of knowledge of the class officers pertaining to these variables and in order for the teachers to help them improve on the particular aspects of democratic leadership and time management attitude where they need improvement.

\section{Limitations of the Study}

In this study, there are also various limitations. First, though the study focuses on all grade levels from Grade 7 to Grade 12, it is only limited to the class officers. Thus, the future researchers may include a bigger sample size for the study to become more reliable.

\section{References}

Adebayo, F. (2015). Time management and students' academic performance in higher institutions, Nigeria. International Research in Education, 3(2), 8-9. https://doi.org/10.5296/ire.v3i2.7126

Adeojo, A. (2012). Effective time management for high performance in an organization. Seinajoki University of Applied Sciences, 73. Retrieved 08 October 2019 from https://www.theseus.fi/

Akcoltekin, A. (2015). High school students' time management skills in relation to research anxiety. Educational Research and Reviews, 10(16), 2247-2248. https://doi.org/10.5897/ERR2015.2345

Amanchukwu, R., Stanley, G., \& Ololube, N. (2015). A review of leadership theories, principles and styles and their relevance to educational management. Management, 5(1), 13. https://doi.org/10.5923/j.mm.20150501.02

Alzalet, K., \& Sandybayev, A. (2019). Time management's effect on efficiency of employees performance: a case of national oil corporation. International Journal of Engineering, Business and Enterprise Applications, 14(1), 5. Retrieved 08 October, 2019, from https://www.researchgate.net/publication/290393969_Time_Management's_Effect_on_Effici ency_of_Employees_Performance_A_Case_of_National_Oil_Corporation

Balkundi, P., \& Harrison, D. (2006). Ties, leaders, and time in teams: strong inference about network structure's effects on team viability and performance. Academy of Management Journal, 49(1), 13. https://doi.org/10.5465/amj.2006.20785500

Bhatti, N., Maitlo, G., Shaikh, N., Hashmi, M., \& Shaikh, F. (2012). The impact of autocratic and democratic leadership style on job satisfaction. International Business Research, 5(2), 197. https://doi.org/10.5539/ibr.v5n2p192

Choi, S. (2007). Democratic leadership: The lessons of exemplary models for democratic governance. International Journal of Leadership Studies, 2(3), 256-258. Viewed 04 October 
2019, from Retrieved from https://pdfs.semanticscholar.org/582c/bd93c2c896b2ac1f301411 23058019ab c045.pdf

Crippen, C. (2005). The democratic school: first to serve, then to lead. Canadian Journal of Educational Administration and Policy, (47), 12-13. Viewed 04 October 2019, from https://files.eric.ed.gov/fulltext/EJ846732.pdf

Dalluay, V., \& Jalagat, R. (2016). Impacts of leadership style effectiveness of managers and department heads to employees' job satisfaction and performance on selected small-scale business in Cavite, Philippines. International Journal of Recent Advances in Organizational Behavior and Decision Sciences, 2(2), 735-748. Viewed 04 October 2019 from http:// globalbizresearch.org/files/5055_ijraob_van-s-dalluay_revenio-c-jalagat-399974.pdf

Desjardins, S., McCall, B., Ott, M., \& Kim, J. (2010). A quasi-experimental investigation of how the gates millennium scholars program is related to college students' time use and activities. Educational Evaluation and Policy Analysis, 32(4), 469-470. https://doi.org/10.3102/0162373710380739

Fisher, E. (2009). Motivation and leadership in social work management: A review of theories and related studies. Administration in Social Work, 365. https://doi.org/10.1080/03643100902769160

Gale, T., \& Densmore, K. (2003). Democratic educational leadership in contemporary times. International Journal of Leadership in Education, 6(2), 134. https://doi.org/10.1080/13603120304819

Harris, A., \& Chapman, C. (2002). Democratic leadership for school improvement in challenging contexts. International Electronic Journal for Leadership in Learning, 6(9), 4. Retrieved 08 October 2019 from https://eprints.gla.ac.uk/75099/1/75099.pdf

Jiang, J. (2014). The study of the relationship between leadership style and project success. American Journal of Trade and Policy, $1(1), \quad 54$. https://doi.org/10.15590/ajtp/2014/v1i1/54054

Jogaratnam, G., \& Buchanan, P. (2004). Balancing the demands of school and work: stress and employed hospitality students. International Journal of Contemporary Hospitality Management, 16(4), 243. https://doi.org/10.1108/09596110410537397

Kavanagh, E. (n.d.). Three leadership models: Kurt Lewin, Hershey and Blanchard, and Edwin Friedman. Retrieved 07 October, 2019, from http://www.earonkavanagh.ca/article_kavanagh-three.pdf

Kensler, L., \& Woods, P. (2012). A nested view of democratic leadership and community. Journal of School Leadership, 22, 702-703. https://doi.org/10.1177/105268461202200401

Khatib, A. (2014). Time management and its relation to students' stress, gender, and academic achievement among sample of students at Al Ain University of Science and Technology, UAE. International Journal of Business and Social Research, 4(5), 54-55. http://dx.doi.org/10.18533/ijbsr.v4i5.498 
Lay, C., \& Schouwenburg, H. (2007). Train procrastination, time management, and academic behavior. Journal of Social Behavior and Personality, 8(4), 659. Retrieved 08 October, 2019 from https://www.researchgate.net/publication/209836122

Liu, L., Rijmen, F., MacCann, C., \& Roberts, R. (2009). The assessment of time management in middle-school students. An International Journal of Research into the Structure and Development of Personality, and the Causation of Individual Differences, 47(3), 177-178. https://doi.org/10.1016/j.paid.2009.02.018

Meer, J., Jansen, E., \& Torenbeek, M. (2010). It's almost a mindset that teachers need to change: First-year students' need to be inducted into time management. Studies in Higher Education, 35(7), 784-788. https://doi.org/10.1080/03075070903383211

Miller, V. (2012). The broad challenge to democratic leadership. Democracy and Education, 20(2), 10. Retrieved 08 October, 2019 from https://pdfs.semanticscholar.org/6527/ fde714188 e54edce59aa54cd19f5c4d8be4c.pdf

Mohamed, O., Hamal, R., \& Mohamed, K. (2018). A study on time management: Case of Northeast Normal University international students. European Journal of Alternative Education Studies, 3(1). 10.5281/zenodo.1161527

Mullins, M. (n.d.). Time management for effective leaders. Leadership Development International. Retrieved 04 October 2019 from https://ldiglobalmissions.files. wordpress.com/2013/03/time-management-for-effective-leaders-m-r-mullins.pdf

Muthoni, M., Njagi, N., \& Wambugu, G. (2018). Assessment of student leaders' skills in managing student affairs in public universities in Kenya. International Journal of Education \& Literacy Studies, 6(4), 108. https://doi.org/10.7575/aiac.ijels.v.6n.4p.107

Nadinloyi, K., Hajloo, N., Garamaleki, N., \& Sadeghi, H. (2013). The study efficacy of time management training on increase academic time management of students. Procedia- Social and Behavioral Sciences, 136-137. https://doi.org/10.1016/j.sbspro.2013.06.523

Nasrullah, S. \& Khan, M. (2015). The impact of time management on the students' academic achievements. Journal of Literature, Languages and Linguistics, 11, 71. Retrieved 07 October 2019 from https://www.researchgate.net/publication/313768789

Nunez, J., Suarez, N., Rosario, P., \& Vallejo, G. (2015). Relationships between perceived parental involvement in homework, student homework behaviors, and academic achievement: differences among elementary, junior high, and high school students. Contemporary Educational Psychology, 392-397. https://doi.org/10.1007/s11409-015-9135-5

Osswatch (2014). Leadership style questionnaire. Viewed 25 September 2019 from https://www.slideshare.net /osswatch/activity2-leadership-style

Panek, E. (2013). Left to their own devices: College students' "guilty pleasure" media use and time management. Communication Research, 11. https://doi.org/10.1177/0093650213499657

Rawson, M. (2011). Democratic leadership in Waldorf schools. Research on Steiner 


\section{Macrothink}

International Journal of Learning and Development

ISSN 2164-4063 2020, Vol. 10, No. 1

Education, 2(2), 12. Retrieved 07 October 2019 from https://www.rosejourn.com/index. $\mathrm{php} /$ rose/article/view/70/98

Rombe, M. (2016). Effective time and self-management, environment and productivity in an organization. Science Journal of Business and Management, 4(6), 210. https://doi.org/10.11648/j.sjbm.20160406.15

Somech, A. (2005). Directive versus participative leadership: Two complementary approaches to managing school effectiveness. Educational Administration Quarterly, 41(5), 780-790. https://doi.org/10.1177/0013161X05279448

Wang, W., Kao, C., Huan, T., \& Wu, C. (2010). Free time management contributes to better quality of life: A story of undergraduate students in Taiwan. Journal of Happiness Studies, 570-571. https://doi.org/10.1007/s10902-010-9217-7

Wayne State University. (2007). Time management personal assessment. Retrieved 25 September 2019 from http://med.fau.edu/healthfirst/Time\%20Management\%20 Questionnaire.pdf

Woods, P. (2004). Democratic leadership: drawing distinctions with distributed leadership. International Journal of Leadership in Education: Theory and Practice, 7(1), 3-26. https://doi.org/10.1080/1360312032000154522

Young, E. (2010). Time management for leaders. Retrieved 07 October 2019 from https:/www.sac.edu/StudentServices/StudentLife/Documents/CLUB\%20RESOURCES \%20\%20RESOURCE \%20LITERATURE/02\%20\%20TIME\%20MANAGEMENT \%20FOR\%20 LEADERS.pdf

Zeidan, H. (2009). The blake and mouton managerial grid identifying the five different leadership styles. 33. Retrieved 01 October 2019 from http://www.dcookacademic.com /uploads /1/0/8/8/10887248/blake_mouton_managerial_grid.pdf

\section{Copyright Disclaimer}

Copyright for this article is retained by the author(s), with first publication rights granted to the journal.

This is an open-access article distributed under the terms and conditions of the Creative Commons Attribution license (http://creativecommons.org/licenses/by/4.0/). 